\title{
Feeding Activity of the Grey Heron Ardea cinerea in Tidal and Non-tidal Environments
}

\author{
Yuji Sawara, ${ }^{1}$ Nobuyuki Azuma, ${ }^{2}$ Kimiaki Hino,${ }^{3}$ Kaoru Fukui, ${ }^{3}$ \\ Gen Demachi ${ }^{3}$ and Muneki Sakuyama ${ }^{3}$ \\ ${ }^{1}$ Department of Biology, Faculty of General Education, \\ Hirosaki University, Hirosaki 036; \\ ${ }^{2}$ Ocean Research Institute, University of Tokyo, Tokyo 164; \\ ${ }^{8}$ Department of Biology, Faculty of Science, \\ Hirosaki University, Hirosaki 036
}

\author{
潮汐のあるえさ場とないえさ場でのアオサギの \\ 採䬣活動の違い \\ 佐原雄二 ${ }^{1} \cdot$ 東 信 行 $^{2} \cdot$ 日野公彰 $\cdot$ 福井 薰 \\ 出町 玄 ${ }^{3}$ 作 山宗 樹 ${ }^{3}$ \\ ${ }^{1}$ 弘前大学教養部生物学教室; ${ }^{2}$ 東京大学海洋研究所; \\ ${ }^{3}$ 弘前大学理学部生物学教室
}

In the course of the studies on the ecology of estuarine fishes, we realized that it was very important to know the foraging behavior of piscivorous birds which had serious effects on the activity pattern of those fishes. Therefore, we started to investigate the foraging behavior of the Grey Heron Ardea cinerea, which was thought to be the major avian predator of demersal fishes inhabiting estuarine environment in Aomori Prefecture. RichneR (1986) studied winter foraging behavior of Grey Herons in an estuary and the adjacent streams in Scotland. He found feeding was restricted to 3 hours both before and after low tide in the estuary, in contrast to the constant diurnal feeding at the streams. Since the water level changes 2.5 meters on an average according to tide in the Scottish estuary (LeACH 1971), but only about $70 \mathrm{~cm}$ in Ashizaki Bay, our study area, it is interesting to investigate whether or not a similar foraging pattern is observed. In the present paper we shall report the foraging behavior and rhythmicity of Grey Herons in tidal and non-tidal environments in Aomori Prefecture.

\section{STUDY AREA}

Ashizaki Bay is a small bay situated at the north of Mutsu Bay (Fig. 1). This small bay is formed by the mainland and a sand-bar which is a part of the Self Defence Force site, and the water surface is generally calm because of protection from heavy wave action. The tidal amplitude is about $70 \mathrm{~cm}$ on spring tide and about $35 \mathrm{~cm}$ on neap tide in Mutsu Bay. The small Usori River flows into Ashizaki Bay at the innermost of the bay. During low tide, mudflats appear around the river-mouth and along the sand-bar (the opposite shore of the observation point). There are sea-weed belts of Zostera nana on lower mudflats and offshore from there. 
Grey Herons occur throughout the year, although few in number in winter (AOMORI Prefecture 1982). They are in large numbers in autumn, probably because of the temporary stopover of northern populations during the southward migration. The largest number we counted was 69 on October 6, 1990. We observed several other piscivorous bird species, including seasonally observable ones, in our study area: the Little Egret Egretta garzetta, Kingfisher Alcedo atthis, Red-breasted Merganser Mergus serrator, Osprey Pandion haliaetus, Little Grebe Podiceps ruficollis and Common Cormorant Phalacrocorax carbo. Although the Night Heron Nycticorax nycticorax was reported to occur (Aomori Prefecture 1982), we have never seen it. The above piscivores are either those which forage at the sites where Grey Herons never forage (Kingfisher, Osprey, Red-breasted Merganser, Little Grebe and Common Cormorant), or those which occur in small numbers if their foraging sites overlapped with the Grey Heron (Little Egret and Night Heron). Thus the Grey Heron is thought to be the most effective avian predator of the fishes inhabiting shallow areas of this estuary.

The fish species inhabiting Ashizaki Bay are classified into two categories; one is demersal species such as four gobiid fishes Tridentiger brevispinis, Chaenogobius castaneus, Acanthogobius lactipes and Acanthogobius flavimanus, the gunnel Enedrias crassispina and the flatfish Platichthys stellatus, and the other is pelagic species such as the smelt Hypomesus transpacificus, puffer Takifugu niphobles, ayu Plecoglossus altivelis, mullet Mugil cephalus and halfbeak Hemirhamphus sajori. Some of the latter species are only seasonally found.

Foraging behavior of Grey Herons in a non-tidal environment was investigated at Mawarizeki Reservoir, which was situated in Tsugaru Plain (Fig. 1). This is a large reservoir (ca. $2.67 \mathrm{~km}^{2}$ ) and many Grey Herons, often more than 100 , visit there during migration temporarily from late August to the onset of freezing of the water surface, which coincides with the period when the water volume of this reservoir remains small. Besides, a considerable number of Large Egrets Egretta alba can be seen there as winter birds.

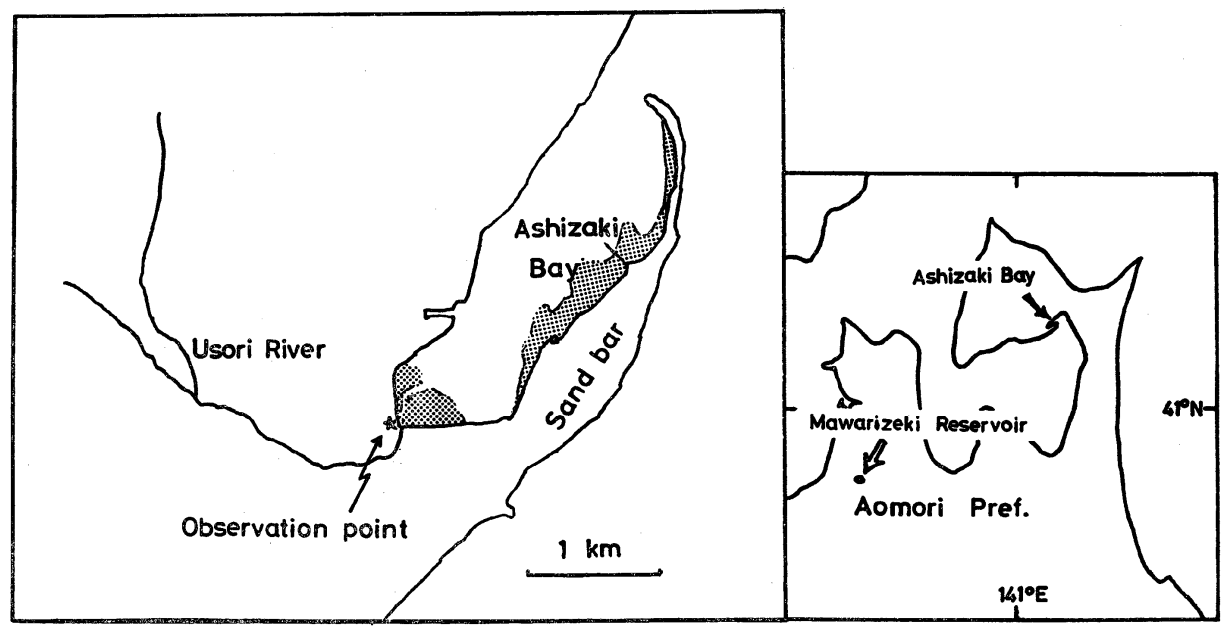

Fig. 1. Map of the study area. The open and closed arrows indicate Mawarizeki Reservoir and Ashizaki Bay, respectively. The map of Ashizaki Bay is shown on the left, with dotted areas indicating mudflats. 


\section{METHODS}

Field observations were made using $20 \times$ and $40 \times$ fieldscopes. The fixed observation point is indicated by $\star$ mark on Fig. 1. From there almost all of Ashizaki Bay can be seen, excepting for only a small distant area of the opposite shore. However, as Grey Herons foraged mostly in the inner part of the bay, we were able to count all individuals wading in water. At the time of observation, their behavior was also recorded when they were sufficiently close. Four observers watched individual herons for 30 minutes, and the behavior of the herons together with the fish size and the fish species taken were recorded by portable tape-recorders at three hour intervals. Prey size was estimated as the relative length to the heron's bill. In the present paper, however, only the results on the prey catching rate of heron were reported. Nighttime observations were also made using a nightscope. However, because of the limitations of resolution and magnification abilities, the observable range was restricted to the vicinity of the mudflat of the mouth of the Usori River. Nevertheless, we succeeded in recording the herons' behavior at night for over one hour, on September 30,1990, using a $8 \mathrm{~mm}$ videocamera with a nightscope attached with a $500 \mathrm{~mm}$ telephotolens.

The observation at Mawarizeki Reservoir was made similarly as in Ashizaki Bay. Since nighttime observations were not possible, the observation period was restricted from before sunrise to after sunset. The conditions for observation were worse than in Ashizaki Bay because of the thick growth of emerged plants and the distance of herons from the observation points (on the bank surrounding the reservoir). We solved this problem by setting several observation points around the reservoir using a car. Thus we were able to count all of the herons wading in water.

\section{RESULTS}

The Grey Heron exhibited a tide-related foraging activity in Ashizaki Bay. Figs. 2-4 show that their foraging period in water is restricted to the period during falling tide and low tide. Grey Herons did not forage while it was raining and/or very windy, probably because of ripples on the water surface (Fig. 3). They were waiting on trees while a strong wind was blowing after trying to forage unsuccessfully for a while. On the other hand, they never foraged while the water level was high.

We also have found Grey Herons foraged at night, at least on some occasions (Fig. 4).

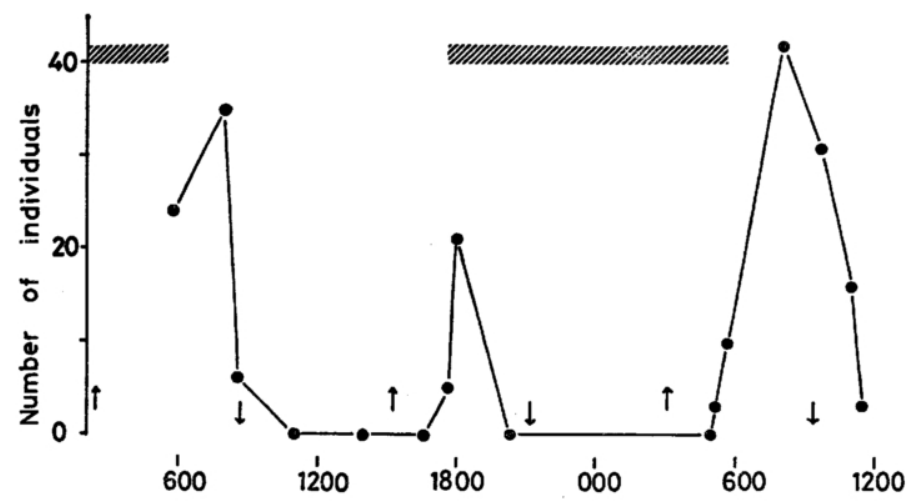

Fig. 2. The change of the number of herons foraging in water, 24-25 September 1988, Ashizaki Bay. Arrows indicate the times of high tide and low tide. 

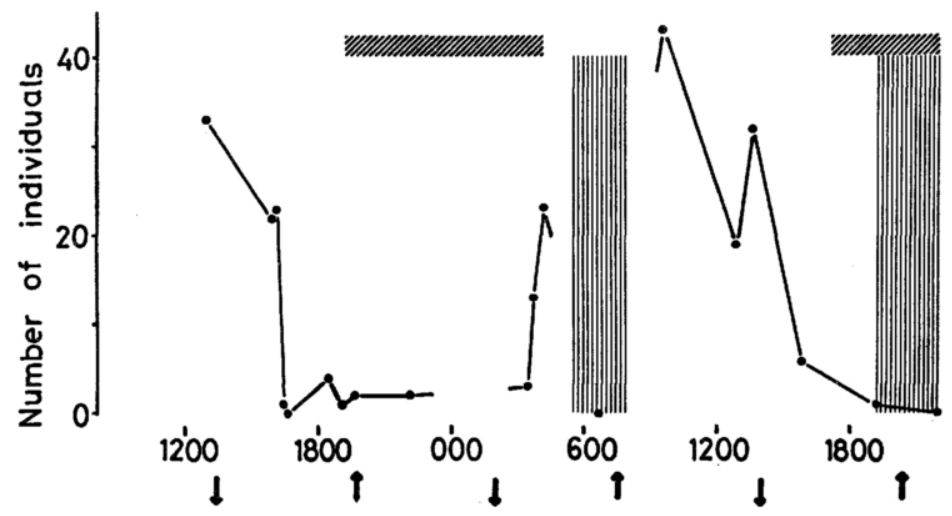

Fig. 3. The change of the number of herons foraging in water, 24-25 June 1989, Ashizaki Bay. Arrows indicate the times of high tide and low tide. Vertically hatching indicates the period of rainfall.

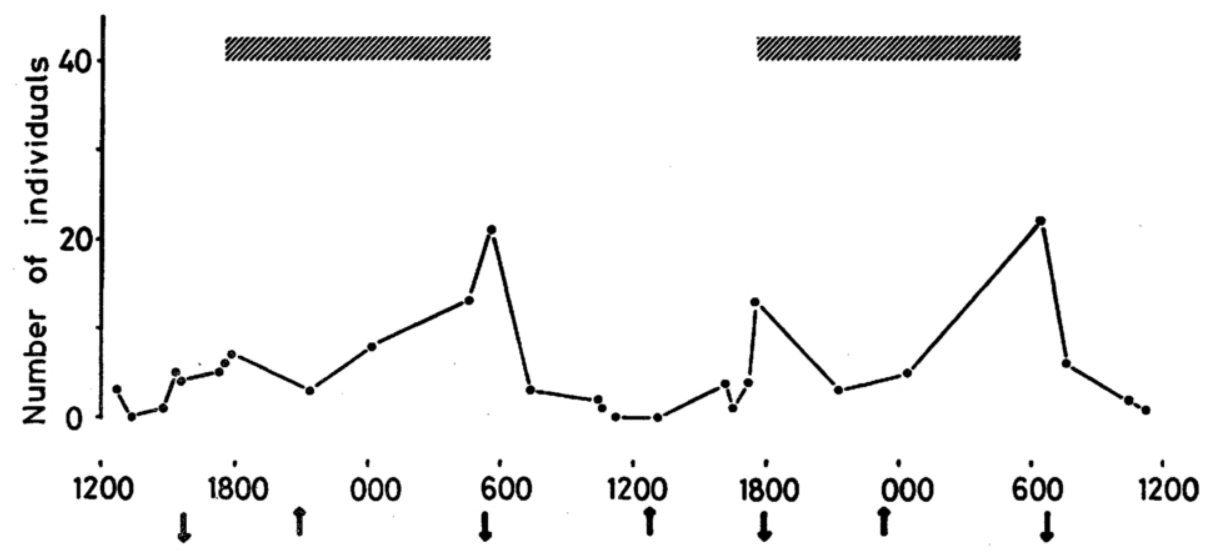

Fig. 4. The change of the number of herons foraging in water, 23-25 September 1989, Ashizaki Bay. Arrows indicate the times of high tide and low tide.

Because the number of herons counted before dawn around the mudflat near the observation point was almost the same as the total number counted in the whole bay after sunrise, most herons seemed to come on this mudflat during the period of low tide while it was still dark. During daytime, however, they foraged on both shores, and rather more herons were found on the opposite shore of the observation point (the sand-bar). This difference of distribution between day and night may be related to their avoidance of men. In fact, a Grey Heron was observed very close to the observation point at night, but never seen during the daytime.

Considering from these results, it can be concluded that the change of water level is much more important as a restricting factor of foraging period of Grey Herons in estuarine environment than the change of light intensity.

The main food items of Grey Heron in Ashizaki Bay turned out to be the gobiid fishes and the gunnel, although we confirmed other fish species were also eaten, such as the flatfish, smelt and puffer. Almost all of the fish eaten were, however, demersal ones. 
On the Ythan Estuary, the main food item of the Grey Heron was also demersal fishes, but it was chiefly the flatfish, corresponding to their abundance there (CooK 1978). The food of Grey Herons in Ashizaki Bay will be reported in more detail elsewhere (SAwARA \& SAKUYAMA in preparation).

On the other hand, the foraging activity at Mawarizeki Reservoir did not exhibit any clear rhythmicity (Figs. 5-7). At least during the daytime, some herons were seen to

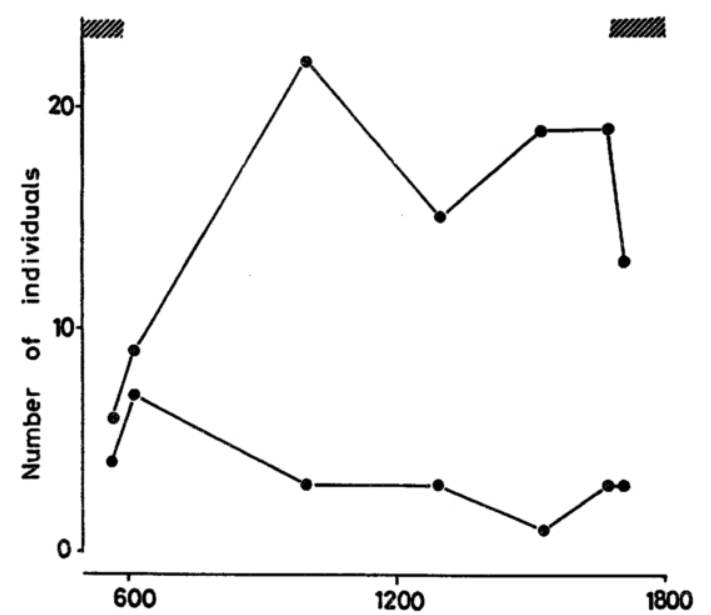

Fig. 5. The change of the number of herons, 22 October 1988, Mawarizeki Reservoir. Upper and lower lines indicate the total number of herons and that of foraging in water, respectively.

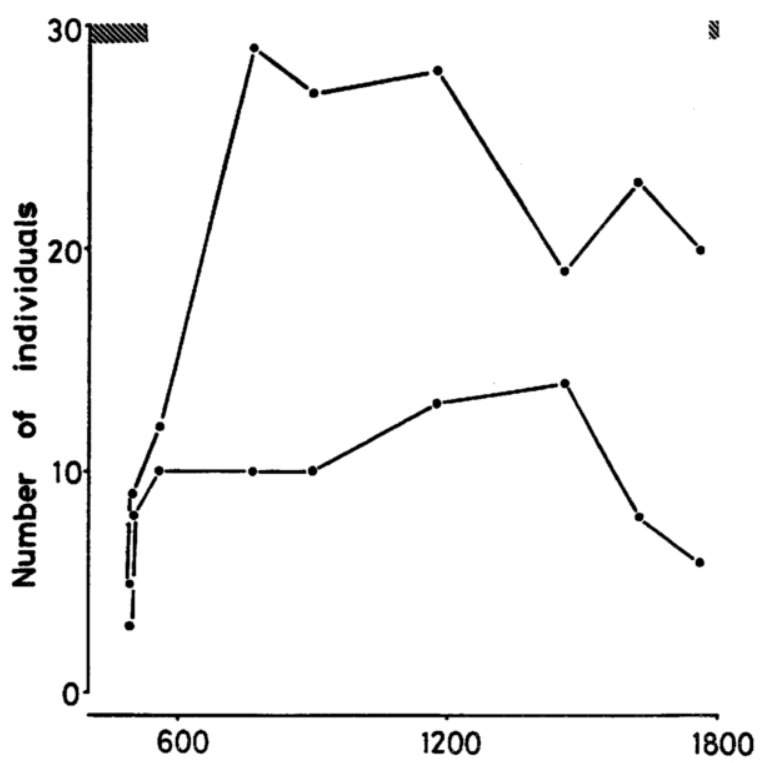

Fig. 6. The change of the number of herons, 12 September 1989, Mawarizeki Reservoir. Upper and lower lines indicate the total number of herons and that of foraging in water, respectively. 


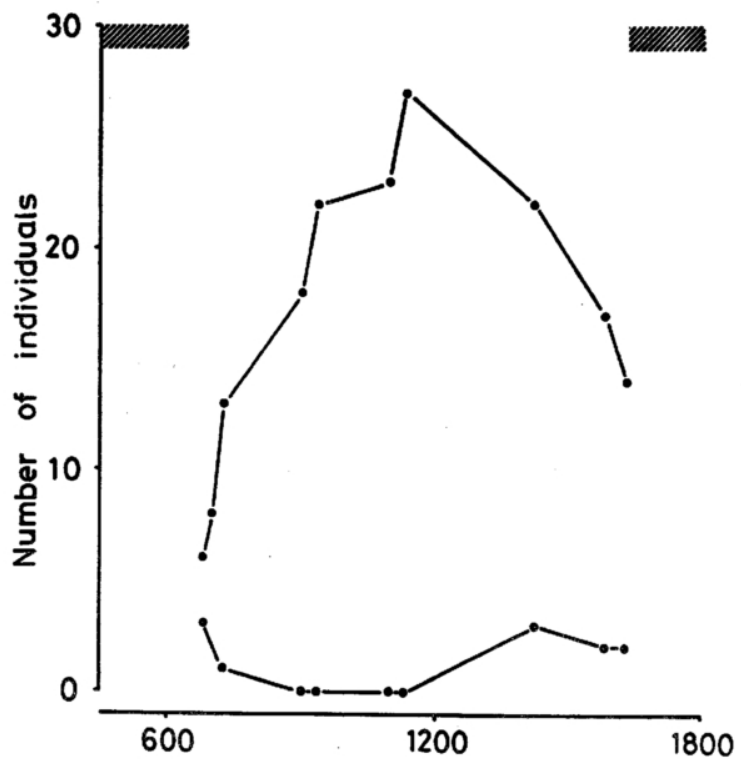

Fig. 7. The change of the number of herons, 12 November 1989, Mawarizeki Reservoir. Upper and lower lines indicate the total number of herons and that of foraging in water, respectively.

be wading in the water at any observation time. The total number of herons counted increased after sunrise on every observation day. It seemed to have resulted from the increased activity, hence increased visibility of herons which were hiding in the vegetation during the nighttime.

The main food item at Mawarizaki Reservoir was not clearly confirmed because of the small size of available data. However, we often observed Grey Herons foraging intensively on small pelagic fish, probably a cyprinid Pseudorasbora parva, in shallow area and once we observed a heron eating a weakened catfish Silurus asotus.

There was a difference in the foraging tactics of Grey Herons between these two habitats. At Mawarizeki Reservoir, most of the herons in water were standing and not moving. On the contrary, the herons in Ashizaki Bay walked much more frequently while foraging. Kushlan (1976) categorized and listed the foraging tactics of heron species in North America. According to Kushlan's classification, the Grey Herons in Ashizaki Bay used the "walking slowly" tactics, while those in Mawarizeki Reservoir chiefly adopted "stand-and-wait" tactics.

The catching rate of fish during foraging was also different between the two habitats. We calculated the average catching rate (catch per capita per minute) of foraging herons in water from the observation data in September, irrespective of the time of day or the age of heron. The average catching rates were 0.175 (Sept. 23-25, 1988; total observation hrs: 510 minutes) and 0.116 (Sept. 23-25, 1989; 232 minutes), in Ashizaki Bay, whereas it was only 0.098 (Sept. 12, 1989; 245 minutes) at Mawarizeki. According to CooK (1978), the prey catching rate of Grey Herons on the Ythan Estuary, where the main food item was the flatfish, during August and September was 0.052 for adult and 0.073 for first-year herons, respectively. These figures are considerably lower than those in the present study, suggesting that the differences in prey species and/or prey size, 
together with prey density, are responsible for the difference in catching rate.

\section{DISCUSSION}

The Grey Herons foraged while the water level was low in tidal environment. This was the same as on the Ythan Estuary in Scotland (RICHNer 1986). However, the tidal range is very different between the two localities. The tidal amplitude in the Scottish estuary is 2.5 meters on an average and much greater than in our study area $(\mathrm{ca} .70 \mathrm{~cm}$ on spring tide). Nevertheless, the pattern in foraging activity was the same between these locations. This means that the water level is a highly restrictive factor of foraging time in any environment wherever tidal change exists.

At Mawarizeki Reservoir where no tidal change exists, on the other hand, Grey Herons forage constantly at least during the daytime. This continuous feeding of heron in non-tidal environment coincided with the observations of RICHNER (1986) in streams. The herons in Mawarizeki Reservoir mainly adopted "stand-and-wait" tactics, contrasting to herons in Ashizaki Bay adopting "walking slowly" tactics almost exclusively. The difference can probably be attributed to the difference of the main prey: in Ashizaki Bay the main prey was demersal fish species, such as goby, gunnel and flatfish, which were generally not active and cryptic in their habitat, but pelagic fishes were probably eaten more often at Mawarizeki. Forbes (1987) found that the Great Blue Herons Ardea herodias adopting "standing" tactics took more active prey, such as yellow perch, whereas herons using "walking slowly" tactics took more sedentary prey such as black bullhead.

However, this difference might be related with the difference in the catching rate of prey, because according to the optimal foraging theory, animals are more likely to use "high cost, high return" tactics is more profitable environment, while "low cost, low return" tactics is more likely to be adopted in less profitable one (Norberg 1977). The catching rate was higher in Ashizaki Bay than at Mawarizeki, and "walking slowly" is naturally supposed to be more costly and higher in energy expenditure than "stand-andwait". At present we have not sufficient data on the herons' diet at Mawarizeki, and this problem is still left for future study.

Grey Herons can not take fish while the water surface is rippled by wind or rainfall, because herons catch prey apparently visually from above the water surface. It is rather surprising to find that Grey Heron forages at night. RrCHNER (1986) reported, however, a heron regularly fished at night under the light of a road lamp on Ythan Estuary in Scotland. In the case of our study area, there was no light source near the observation point, except for a dim gate lamp of the Self Defence Force, the illuminated range of which was small, and moreover, the sky was rather cloudy on that day.

However, night foraging of heron did not seem to be as efficient as in the daytime. During one hour videotape record, successful catch of prey was only once, though the time period was after the time of low tide, and therefore the feeding activity then might be low. That herons forage at night despite of the low foraging rate may be related to the short period available to forage, which is restricted by the change of water level. The time length available for foraging during a tide was about 6 hours at most (Figs. 2-4). While the water level was high, herons were found resting on the beach of the opposite shore, or they flew away to other feeding sites such as reservoirs and ricefields.

\section{ACKNOWLEDGMENTS}

We express thanks to Kouichi Tani, Atsuki Azuma, Munenobu TorikaI, Yumi SaSAKI and 
Takeyuki NAKamura for their help in our field work and to Janice Seino for her reading of the early version of the manuscript. Thanks are also due to Tohru Kurimura, Ohminato Senior High School, for the information on the field, and to Masaru ShIogaki, Aquaculture Center of Aomori Prefecture, for the identification of the gunnel.

\section{SUMMARY}

The foraging activity rhythm of the Grey Heron was observed in Ashizaki Bay, an estuarine habitat, and at Mawarizeki Reservoir, a non-tidal habitat, both in Aomori Prefecture. In Ashizaki Bay, herons foraged while the water level was low, although the tidal range was about $70 \mathrm{~cm}$ on spring tide. Herons foraged also during the nighttime low tide. In non-tidal habitat, on the other hand, they foraged constantly throughout the daytime. Herons foraged on fish using "walking slowly" tactics in Ashizaki Bay, whereas they foraged using "stand-and-wait" tactics at Mawarizeki Reservoir. This difference was thought to be attributable to the difference in main prey item (demersal fish species in Ashizaki Bay vs. pelagic fish at Mawarizeki Reservoir) and/or difference in prey catching rate (high rate in Ashizaki Bay vs. low rate at Mawarizeki).

\section{要 約}

青森県の, 潮汐のある芦崎湾および潮汐のない廻堰大溜池で, アオサギの採飭活動周期を観察した. 芦崎湾の潮位差は大潮でもわずかに $70 \mathrm{~cm}$ ほどであるが, それでもアオサギの採慨活動は潮汐周期が 明白で, 採餌時間帯は低潮の前後に限られていた. 一方, 潮汐のない廻堰では, 少なくとる日中は採䭒 活動が継続的に行われていた。 また, 芦崎湾では夜間の低潮時にも採餌が見られた. 主に底生魚を捕 食する芦崎湾では, アオサギは「ゆっくり歩く」方法で採慨したが, むしろ浮き魚をとる迴堰では「立 ったまま待つ」方法で採餌した. 時間当りの魚の捕獲率は芦崎湾の方が迴愝より大きかった.

\section{LITERATURE CITED}

Aomori Prefecture, 1982. Report on the distribution of wild mammals and birds in Aomori Prefecture. Aomori, Aomori Prefecture. (in Japanese)

Cook, D. C., 1978. Foraging behaviour and food of Grey Herons Ardea cinerea on the Ythan Estuary. Bird Study 25: 17-22.

Forbes, L. S., 1987. Feeding behaviour of Great Blue Herons at Creston, British Columbia. Can. J. Zool., 65: 3062-3067.

Kushlan, J. A., 1976. Feeding behavior of North American herons. Auk 93: 86-94.

LEACH, J. H., 1971. Hydrology of the Ythan Estuary with reference to distribution of major nutrients and detritus. J. mar. biol. Ass. U.K. 51: 137-157.

NorberG, R. A., 1977. An ecological theory on foraging time and energetics and choice of optimal food-searching method. J. anim. Ecol. 46: 511-529.

RICHNER, H., 1986. Winter feeding strategies of individually marked herons. Anim. Behav. 34: 881-886. 